\title{
The re-appreciation of the humanities in contemporary philosophy of science: From recognition to exaggeration?
}

\author{
Author: \\ Renato Coletto ${ }^{1}$ \\ Affiliation: \\ ${ }^{1}$ School of Philosophy, \\ North-West University, \\ Potchefstroom Campus, \\ South Africa \\ Correspondence to: \\ Renato Coletto \\ Email: \\ renato.coletto@nwu.ac.za \\ Postal address: \\ Private Bag X6001, \\ Potchefstroom 2520, \\ South Africa \\ Dates: \\ Received: 25 July 2012 \\ Accepted: 13 Feb. 2013 \\ Published: 21 June 2013 \\ How to cite this article: \\ Coletto, R., 2013, 'The \\ re-appreciation of the \\ humanities in contemporary \\ philosophy of science: From \\ recognition to exaggeration?', \\ Koers - Bulletin for Christian \\ Scholarship 78(2), Art. \#64, \\ 7 pages. http://dx.doi.org/ \\ 10.4102/koers.v78i2.64

\section{Copyright:} \\ C 2013. The Authors. \\ Licensee: AOSIS \\ OpenJournals. This work \\ is licensed under the \\ Creative Commons \\ Attribution License. \\ Read online:

In the course of the centuries, the 'reputation' and status attributed to the humanities underwent different phases. One of their lowest moments can be traced during the positivist period. This article explored the reasons underlying the gradual re-evaluation of the scientific status and relevance of the humanities in the philosophy of science of the 20th century. On the basis of a historical analysis it was argued that on the one hand such recognition is positive because it abolishes an unjustified prejudice that restricted the status of 'science' to the natural sciences. On the other hand it was argued that the reasons behind such recognition might not always be sound and may be inspired by (and lead to) a certain relativism harbouring undesired consequences. In the final part of this article (dedicated to Prof. J.J. [Ponti] Venter) a brief 'postscript' sketched his evaluation of the role of philosophy.

Die herwaardering van die geesteswetenskappe in die kontemporêre wetenskapfilosofie: Van erkenning tot oordrywing? Die 'reputasie' en status van die geesteswetenskappe het deur die eeue heen veranderinge gedurende die verskillende fases ondergaan. Een van die grootste laagtepunte kon gedurende die positivistiese periode waargeneem word. Hierdie artikel het die redes onderliggend aan die toenemende herwaardering van die wetenskaplike status en relevansie van die geesteswetenskappe in die wetenskapsfilosofie van die twintigste eeu ondersoek. 'n Historiese analise is as basis gebruik waarvandaan geargumenteer is dat hierdie erkenning aan die een kant positief is omdat dit die ongeregverdigde vooroordeel wat die status van 'wetenskap' tot die natuurwetenskappe beperk, omverwerp. Aan die ander kant is geredeneer dat die redes vir hierdie erkenning nie altyd suiwer is nie en geïnspireer mag wees deur (en lei tot) 'n soort relatiwisme wat ongewenste gevolge huisves. In die finale deel van hierdie artikel (opgedra aan Prof. J.J. [Ponti] Venter) is sy evaluering van die aard en rol van die filosofie in 'n kort 'naskrif' geskets.

\section{Introduction}

When we start asking questions concerning the status of the humanities ${ }^{1}$, beginning with the positivist movement, we discover that the initial attitude was rather 'unfriendly'. There was a high level of optimism towards the liberating effects of science, yet only or mainly the natural sciences were accredited as sciences. The humanities were not always and not completely excluded from the scientific realm, but somehow the feeling was that they had to become scientific. The royal way to accomplish this was to adopt the methods of the natural sciences. Up to the present, when we say 'philosophy of science' we often mean the philosophy of the natural sciences (as if there were no other sciences). This is a simple but vivid example of the persistence of the positivist legacy.

Gradually, however, the attitude towards the humanities changed. Slowly but increasingly, the humanities gained more 'respectability' and were increasingly appreciated in the works of Popper, Kuhn, Feyerabend, in neo-Marxism and so on. ${ }^{2}$ One could even say that the situation was gradually reversed since the natural sciences are in the postmodern times sometimes invited to adopt the methods of politics or hermeneutics. It is argued that there are not (and should not?) be any differences between the humanities and the natural sciences. Perhaps, in some sense, the natural sciences can even be regarded as part of the humanities?

The main focus of this article is to explore the reasons behind this gradual change of attitude for the purpose of evaluating the process in an informed way. From the author's (reformational) point of view, the recognition of the scientific status of the humanities and of their indispensable role in scholarship is a positive move. The humanities should be regarded as sciences because they

1.In this article I list as 'humanities' all the sciences that are not 'natural' (therefore the social and cultural sciences as well - cf. Strauss 2001 ).

2.Our historical survey will stretch up to the early 1990s. This arrangement will allow us to explore a sufficiently extended period of time, in order to prove that the pattern of re-appreciation developed gradually but persistently. It will also allow us to include in our exploration the most authoritative voices in contemporary philosophy of science. To keep the historical survey within suitable limits, the most recent decades are not included. It should be noted however, that the re-appreciation or integration-trend continues up to the present. 
study reality through 'points of entry' constituted by several modal aspects, just like the natural sciences. However, the motivations behind this gradual re-appreciation of the humanities may not always be sound and may be inspired by (and lead to) a rather relativist position with dire practical implications. In some cases (cf. Feyerabend 1975) one has the impression that almost everything can be regarded as science (or perhaps nothing). In other cases, it does not matter much, because science has nothing special to offer and cannot be distinguished from other activities in 'life'.

After completing a historical overview of the re-appreciation process I will briefly sketch a reformational evaluation and response and, as this article is dedicated to prof. J.J. (Ponti) Venter, I will also briefly outline his own understanding and assessment of the nature and role of one of the human sciences, namely philosophy.

\section{Brief background: Positivism and beyond}

The positivist attitude towards the humanities is somehow ambivalent. On the one hand, an immense fascination with the natural sciences led many authors to oppose facts and values, physics and metaphysics, objectivity and subjectivity. Of course, the natural sciences were on the side of objectivity and of the facts, whilst the humanities were on the other side. On the other hand, it is interesting to note that Comte (1830-1842) included sociology in his list of scientific disciplines. Actually, sociology had a sort of 'overarching' function and it was placed 'at the top' of the six sciences (mathematics, astronomy, physics, chemistry, biology, sociology in 'ascending' order). It is also interesting to note that very ancient disciplines like law and history were not considered scientific by the 'father' of positivism. In general, however, positivism left the door open to the possibility that at least some of the humanities might acquire scientific status. In order to do so, unfortunately, they were required to adopt the method of the natural sciences. Sociology was already called 'social physics' by Comte, and was supposed to study social phenomena with the same impartiality and precision attributed to physics.

In positivist circles philosophy was treated with particular suspicion, it was often called 'metaphysics' and was part of the presuppositions that should be left outside the laboratory door. All in all, it was mainly natural science that enjoyed full recognition. Science was the only system following the path of verification and 'non-scientific' became a synonym of meaningless.

The humanities, however, were already knocking at the door of academic recognition. Dilthey (1989), Rickert (1896-1902) and Weber (1949) tried to attach either a different method or a different object of study to the human sciences. Dilthey (1989:56ff, 436-440) argued that the method of the natural sciences is totally inadequate to study history or social and cultural achievements. History is the product of human beings and is as such not reducible to natural objects. As a consequence, a totally different method is required: the imaginative re-creation of the experiences of others.
Although rejecting the ontological dualism underlying Dilthey's views, Rickert (1896-1902) accepted and explored further the idea of an alternative method suitable to the humanities. The nomothetic method is suitable for the natural sciences, but the ideographic method suits the humanities. The first method focuses on the universal whilst the second focuses on the individual and unique. The distinction is not based on ontology but on logic, as the same reality can be regarded as nature or as history. Finally, Weber (1949:50ff) argued that this difference in method does not decrease the objectivity of the social sciences; it rather integrates an otherwise unilateral understanding of the world.

\section{Opening a back-door to the humanities}

Although their approaches differ, all these German authors created an alternative to positivism and opened a door (at least a back-door) to the humanities. Popper walked some extra miles for the humanities' sake. In opposition to the positivist mentality he (Popper 1963:38) stated that 'nonscientific' is not equivalent to non-sensical or meaningless. There is meaning and knowledge outside of science. At the same time, however, science remains for Popper a 'superior' type of knowledge, so to speak, and by 'science' he basically means natural science (physics in particular).

In a recent article (Coletto 2011), Popper's views on the topic were outlined by saying that science is present wherever we have universal laws. The scientific attitude requires first of all conjectures and refutations, in other words the possibility of falsification. In addition, however, science is present only when dealing with universal laws, which Popper detects especially in the physical dimension. According to Popper we do not have universal laws in the historical or social dimension (one could say: aspect), therefore we cannot have fully-fledged science. This is the reason why, it was argued (Coletto 2011:68), Popper could regard psychology and sociology as 'spurious sciences' that are 'riddled with fashions and with uncontrolled dogmas'. He could therefore write to Kuhn: '[I hope] you do not want to appeal to the sociological (or psychological or historical) lunatic fringe' (Popper 1970:57-58).

All this is true, but in some instances Popper attenuated and nuanced this rather harsh position, still much indebted to positivism. Perhaps these nuances originate in part from the fact that they appear in a context of dialogue with neoMarxism, in a volume edited by Adorno (cf. Popper 1976). One could also notice that they were written a few years later (1976) than the above quoted texts of 1963 and 1970 and probably further reflection had played its part.

Whatever the reason, the picture seems to change. In 'The logic of the social sciences' (Popper 1976) there seems to be little difference between the natural and the social sciences. Apparently the latter use exactly the same method as the former: conjectures and refutations. By means of communal criticism they both falsify their theories and retain the most corroborated ones. Objectivity is not excluded in the social 
sciences because it depends on the critical method, not on the field of study. The research process starts with a problem and observation follows, exactly as is the case of the natural sciences (Popper 1976:87-90). Positivism, says Popper (1976:90ff), wanted the social sciences to adopt the same method of the natural sciences, namely the inductive method. But that was the wrong solution. (As a matter of fact, Popper too wants the same method to be adopted by both types of sciences; the only difference is that he regards the deductive approach as the right method.)

When considering the different approaches Popper adopted on this issue, one can find a sort of ambivalence and, after all, it should not be too surprising. In fact, Popper's philosophy constitutes a 'bridge' between positivism and the new philosophy of science. This ambivalence was already noticed by Botha (1986) in relation to Popper's appreciation of philosophy: On the one hand Popper warns against the 'bewitching' effects of 'metaphysics', on the other he makes clear philosophical choices and defends them (Botha 1986), for example by endorsing realism and the existence of natural laws.

\section{Opening the front door to the humanities?}

Kuhn is the main representative of the 'historical school' of philosophy of science. This school operated a strong rehabilitation of the role of history in philosophy of science. Kuhn also realised that psychological and social factors play a large role in science (economic factors were mentioned less often). These factors may still be 'external' to science (Kuhn 1996:ix-x), but one cannot understand science without understanding them, and for that reason the humanities become important.

In Kuhn's case the front door is only half-opened, because his system requires that we have science only in the presence of a paradigm accepted by all the 'schools' in a certain discipline, at least for a certain period of undisputed reign. Now, if it is rare to see this situation in the humanities they cannot be fully scientific; they must still be caught in the preparadigm phase, preceding 'normal' or 'mature' science. It is not excluded that they might one day reach a common paradigm (and maturity, or normality with it) but at least for the moment Kuhn still calls them 'proto-sciences' (Kuhn 1970:244ff), 'fields', or 'activities' (Kuhn 1996:195; 208-210). Nevertheless, one might say that even though the scientific status of the humanities was not fully recognised by Kuhn, their usefulness was largely appreciated. Furthermore, Kuhn (ibid:138) pointed out that students of the natural sciences are disadvantaged with respect to their colleagues in the humanities, in the sense that the latter are in fact more aware of different approaches (paradigms) in their disciplines and more knowledgeable of the history of their disciplines.

It is probably Lakatos who opened the front door with conviction. In order to see it, one should briefly follow his view of the criterion for demarcation (between science and non-science). Even though he was a 'disciple' of Popper,
Lakatos did not agree that falsification is the best criterion to distinguish science from pseudo-science. Instead, Lakatos first of all enlarges the picture: the units of great scientific developments are not single theories but research programmes. Usually theories are only the 'hard core' of such programmes and they are surrounded by a host of protective hypotheses that can always justify anomalies or partial refutations of the hard core (Lakatos 1978:110).

The main difference between research programmes is that some of them are progressing and others are degenerating. Degenerating programmes are those that 'lag behind the facts': they are trying to explain what is already known. Marxist historiography, for example, 'explained' the rising living standards of the working class in capitalist countries, and the conflict between China and the Soviet Union. It explained why the first socialist revolution occurred in nonindustrialised Russia, and it explained Berlin 1954, Budapest 1956, Prague 1958 (Lakatos 1978:6). But all these explanations were constructed after the events to 'protect Marxian theory from the facts'. This is an example of a stagnating research programme. Progressive programmes, by contrast, are rich in predictions and in this way they anticipate the facts. Therefore progressive programmes are regarded as scientific, whilst regressive programmes are not.

Whether this criterion is useful or not to distinguish science from pseudo-science is not our main concern here (one might in fact argue that it evades the demarcation problem). What is interesting for our present topic is that Lakatos does not exclude the humanities from his argumentation. Should Marxian theory have made successful predictions, it could have been regarded as progressive and scientific. The dividing line between science and non-science does not run across disciplinary boundaries (e.g. natural versus social sciences) but across research programmes. This changed the discussion deeply and was of course appreciated by scholars in the humanities. Appreciated and often appropriated. For example, Nancey Murphy (1990), in her attempt to prove that theology is a science, adopted Lakatos' criteria and felt entitled to conclude that (at least some) theological research programmes can be considered scientific.

\section{In the front door and out the back door?}

When it comes to Feyerabend we have the feeling that he has no problem with recognising the scientific status of the humanities. In his Against method (Feyerabend 1975) he shows appreciation and knowledge of the history of art, knowledge of philosophy, theology (even Christology), and other disciplines. Collectively they enable him to conduct a discourse on science and help him arguing about science. It is true that here and there he delivers a few harsh remarks on theology and philosophy (cf. Feyerabend 1975:46, 301), but this is due to his provocative style ${ }^{3}$ rather than to any real opposition to the humanities.

3.In his typical style Feyerabend (1975:301) 'classifies' philosophy (of science) amongst the 'bastard subjects ... which have not a single discovery to their credit'. 
The problem is rather that with Feyerabend (1975) both natural and human sciences lose much of their 'value'. He is not fascinated by rationality but by life, passion and freedom. He is against the separation of science and life, in the sense that science should return to be part of life and should resemble ordinary activities as much as possible. There is nothing special about science and natural science is constantly compared and associated with the humanities, but also with all sorts of pre-scientific ideas and activities, myths, beliefs and so on. It was this type of attitude that was extremely frustrating to Popper and prompted some of his most amusing remarks (like the complaint: 'To some, science is nothing but glorified plumbing!' [Popper 1963:102]).

Feyerabend's anarchism, however, was probably not likely to be adopted by large sectors of the philosophical community. More convincing voices, more 'solid' ideologies had to enter the scene, in order to consolidate the 'reputation' of the humanities. Amongst them was neo-Marxism.

\section{Habermas and human interest}

Although Popper (1963:102) was quite frustrated by those who regarded science as 'gadget making', was he not the one who introduced interest as a key-element in science? Science starts with a problem, he argued. We are not merely interested in truth; we want interesting truth (Popper ibid:229). Now, only human beings have interests and problems. The emphasis on these themes is therefore an emphasis on the (human) subject of knowledge or research. Feyerabend (1975) built his own approach on this foundation. From a less radical perspective, Habermas wrote Knowledge and human interests in 1971.

For Habermas (1971:308-311), science can be categorised into three different types, each characterised by specific interests (see Table 1).

Of the three categories, the emancipatory interest is the most important, since it is supposed to direct our understanding of the two other interests. As a consequence, the sciences characterised by interest acquire extraordinary importance and a crucial role. Habermas (1971:198) goes as far as affirming that all the sciences should subordinate themselves and their interests (e.g. technical control) to the systematic sciences. Accepting this priority is equivalent to adopting 'critical science' as opposed to 'traditional science' (a distinction already introduced by Horkheimer). This crucial programme, in line with the humanist project, requires the return of the human agent to the centre of the scientific enterprise and the Humanities (or at least some of them) are finally placed at the top. The natural sciences, in a sense, are placed at the bottom.
Following Kant, Habermas (1984) regard science as one of the 'three spheres' of culture, together with art and morality. In line with the project of the Enlightenment, the three spheres should be fairly distinguished from each other because their confusion always breeds catastrophes (for example the aesthetisation of politics is typical of Nazism). The three types of science must therefore retain a specific identity and are not to be confused with other types of activities, in other 'spheres'. This is in line with 'the project of modernity' that, according to Habermas, should not be abandoned but rather completed. In fact, most of the problems of Western societies, lamented by many, are not due to modernity itself but to the fact that its project 'has not yet been fulfilled' (Habermas ibid:13).

Very soon, however, this approach was to be challenged in two directions: a more radical, left-oriented project (Lyotard 1984) and a more pragmatist and 'conservative' project (Rorty 1991). Leaving apart the political dimension of this conversation, in the next section, we will ask what it implies for the status of the humanities.

\section{Lyotard and Rorty}

It is not easy, I think, to understand the role Lyotard reserves for the humanities in his The postmodern condition (1984). Perhaps this is partially due to the fact that he links his argumentation to the 'three spheres' debate. Science is one of the spheres and has its own 'language game', but what does it include? Lyotard seems to have in mind especially the natural sciences. If so, where does he place the humanities?

We surely make no mistake by saying that Lyotard in the end wants to reduce the contrast between the 'sciences' and 'narrative knowledge'. To him there are no big differences between the methods of politicians and those of scientists. Yet, interestingly, Rorty (1991:86) observes that Lyotard argues as if this was a recent change in the nature of science; as if the empiricist account of science was correct in the past, whilst now science has changed and has become 'postmodern'. May one speak of a strange combination of positivism and relativism in Lyotard? On the one hand Lyotard seems to agree with Hesse that 'the logic of science is circular interpretation, re-interpretation and self-correction of data in terms of theory and theory in terms of data' (Hesse 1980:173). On the other hand, he seems to stick to distinctions and categories that are typical of empiricism.

Nevertheless, I have difficulties imagining a 'positivist' Lyotard. I am rather inclined to think that some of his categories are borrowed for the sake of dialogue, in particular with those who may still consider science as a unique language game. In the end, his message is that the sciences should not be linked

TABLE 1: Habermas' classification of scientific disciplines.

\begin{tabular}{lll}
\hline Type of sciences & Type of interest & Examples \\
\hline The empirical-analytical sciences & Cognitive interest in technical control over objectified processes & Natural sciences \\
The historical-hermeneutic sciences & $\begin{array}{l}\text { Constitutive interest in the preservation and expansion of the inter-subjectivity } \\
\text { of possible action-orienting mutual understanding }\end{array}$ & History, linguistics \\
The systematic sciences of social action & Emancipatory cognitive interest & Economics, sociology, political science, philosophy \\
\hline
\end{tabular}


to any meta-narrative (e.g. Habermas' 'emancipation') but should rather be legitimised for 'the simple fact that they do what they do' (Lyotard 1984:23). If 'language game' is the common denominator of all social activities, there cannot be a huge difference between 'science' and the humanities.

Rorty (1991:87) seems to agree with this interpretation of Lyotard, but he still reproaches him for holding to some 'of the left's silliest ideas' and to their consequences (Rorty ibid:95). For example, according to Rorty (ibid:95), Lyotard has not sufficient consideration for (scientific) communication and consensus, and permanent revolution simply cannot be the purpose of science (Rorty ibid:85-86). But how does Rorty himself see the role of the humanities?

First of all, the problem of the 'three spheres' of Hegelian and Kantian memory should be abandoned: it is just a problem for an 'isolated order of priests'. According to Rorty there is no need for universal foundations. He suggests let us leave the spheres of culture to do what they can do. As one may predict, Rorty wants to look back at Dewey and Bacon with their pragmatic spirit, not towards a future or virtual 'postmodern science'. But surprisingly, it is Dewey himself who drives him towards the future, and prophetically announces the day when 'science and emotion will interpenetrate, practice and imagination will embrace. Poetry and religious feeling will be the unforced flowers of life' (Rorty 1991:95).

After quoting this passage, Rorty (1991:95) reveals: 'Much of what I have been saying is an attempt to follow up on this passage from Dewey'. In agreement with Dewey, the humanities should not be considered 'inferior' to the natural sciences. In agreement with Lyotard, Rorty states: 'The point that there are no interesting epistemological differences between the aims and procedures of scientists and those of politicians is absolutely fundamental' (Rorty ibid:92). In conclusion, we have reached the point where the differences between natural sciences and humanities can vanish without problems.

Here we can conclude our historical survey and say that (although the process was not always linear and 'smooth'), contemporary philosophy of science gradually re-established the role and status of the humanities. Several strategies were used: initially Rickert and Weber pointed out that the humanities are different from the natural sciences and therefore should not be asked to endorse the same method or to treat their objects of study in the same way. Later on, however, the strategy changed. As soon as the humanities reached sufficient 'prestige' the idea that they are similar to natural science returned, but this time it was in order to argue that the natural sciences have nothing different from the humanities!

\section{Interlude: Apart from the philosophers ...}

Before proceeding to an evaluation of the views outlined above, it is necessary to remember that we have been dealing only with the opinions of philosophers of science. Yet they do not represent 'public opinion' or a widespread feeling in society. On the contrary, evaluations can be quite different when we hear the voices of special scientists, technicians, managers or the voice of the 'person on the street'.

Generally speaking, the 20th century has known a gradual loss of confidence in science and technology. The optimism of the 18th century and 19th century, when science promised to lead to the truth and even to victoriously replace other forms of knowledge, was definitely abandoned. At the end of the 19th century science started to show the grim face of industrial exploitation, and later on the face of the nuclear threat, pollution and so on. A recent advertisement of a face cream juxtaposes a group of scientists and an attractive lady who uses the product. Who is one supposed to trust? The beautiful lady of course: she has practical knowledge of the product. Although some scholars are still trying to win scientific respectability for their discipline, we are no longer in the 'age of reason' or 'age of science'. ${ }^{4}$ We live in postmodern times, and other agencies and human faculties are considered reliable.

Nevertheless, science is not totally depreciated, at least not by everybody: the utilitarian, economically driven and technicistic spirit of our times still has a big impact. For example, currently all forms of engineering are held in high esteem, at least in some circles, together with computer sciences and economics. In addition, whatever is vaguely perceived as 'useful' or 'practical' is highly valued, from medical research to military strategy. Management is highly rated and probably overestimated. Amongst the humanities I would say education and politics may retain some credibility, but not much more is still 'in fashion'. Finally, at universities whatever can have economic relevance is highly appreciated. A recent report by the Academy of Science of South Africa (ASSAf 2011) acknowledges that in South Africa the humanities are weakening within the academy and overlooked in society (ASSAf ibid:14). The conclusion (fortunately), amongst some leading academic thinkers in South Africa is that the humanities need to be supported philosophy in particular (ASSAf ibid:124-131).

The 'reputation' of the humanities will greatly depend on the countries that we consult, on the periods that we take into account and on the circles (professional, academic, et cetera) expressing their opinions. This brief 'interlude' is just to help us to keep the broader picture in mind and not to exchange the developments of philosophy of science for public opinion.

\section{By way of evaluation and conclusion}

From a reformational point of view the gradual re-appreciation of the humanities is a positive phenomenon, at least partially. The idea that there are universal laws only in physics or biology is due to a reductionist ontology. It might be true that the natural sciences deal with laws and the humanities deal with norms (the latter requiring human positivisation). But the difference between the two is not as large as Popper seems 4.Phrases like these recur often in the titles of articles and books by theologians who try to establish the scientific status of theology (cf. Barbour 1990 and Murphy 1990). 
to believe (Strauss 2001). The theory of modal aspects paves the way for regarding as sciences all the disciplines exploring reality through one (or more) modal aspect and therefore the re-appreciation of the humanities can be considered positive.

There is, however, some concern about the way the 'rehabilitation' of the humanities was achieved. One might in fact wonder whether it was not reached 'at the expense' of the natural sciences. In other words one might have the impression that whilst the positivists emphasised the more basic modal aspects (physics, movement, number, et cetera), more recent trends emphasise aspects like the historical, the social, the economic and so on. It should be observed that the first modalities constitute the points of view of natural science, whilst the higher modalities 'belong' to the humanities.

Is this fascination with higher aspects the reason why nowadays, in some cases, the humanities seem to become even 'more scientific' than the natural sciences? Could it be the reason why the natural sciences are subtly invited to adopt the method of the humanities and even to recognise themselves as humanities? Are we operating a simple reversal of a previous hierarchy (see Habermas [1971:308-311]?) If this is the case, then the gradual re-evaluation of the humanities might be heading towards new forms of relativism (cf. Feyerabend 1975). In fact, the absolutisation of the historical or the social aspect normally places considerable emphasis on the subject of scientific knowledge. Science may then be placed within the historicist flux of paradigm-changes, with its revolutions leading nowhere and its scientific community as the supreme arbiter of truth and falsehood.

A few concrete problems are likely to affect an academic community in the grip of this relativistic mood, especially when relativism is 'economically inspired' (cf. Venter 2006:288ff). Likewise Feyerabend (1975:306-308) started finding similarities between science and voodoo (or even prostitution), the temptation to legitimise subjects, courses and modules that are far from scientific will increasingly affect a university. In other words, we will deal more and more with what Storkey (1986) calls the 'surrogate sciences', stuff which does not belong in a university but is designed for purposes of economic convenience. A recent signal of malaise is the fact that schools and faculties try to grab for themselves and offer subjects which are beyond their competence for the (not even well disguised) purpose of increasing their student numbers (and financial subsidy with them). ${ }^{5}$

The only safeguard against this relativistic drift would be the recognition that universal norms (conditions) are available both to the natural sciences and to the humanities (but of course not to the 'surrogate sciences'). In other words, a demarcation criterion is needed which recognises the many differences between sciences, but at the same time affirms their common scientific status. This requires a non-reductionist ontological

5.At our own Potchefstroom Campus, for example the philosophy of the natural sciences or social philosophy are taught directly by the schools of physics or sociology. What a student can normally get, in these cases, is a survey of different 'paradigms' within a student can normally get, in these cases, is a survey of different 'paradigms' within
those subjects, usually with insufficient deepening of the underlying philosophical themes. background, one which does not lead to the 'veneration' of one or other series of modal aspects (for example the ones qualifying the objects of study of the natural, social, or cultural sciences). For the moment, reductionism and absolutisations unfortunately remain strong temptations for several trends in philosophy and scholarship. As long as they coincide with uncertainty and disagreement on the criterion to distinguish between science and non-science, my forecast is that ambiguity, arbitrariness and self-interested pragmatism will not be easily eliminated. But of course, nothing prevents better choices from being adopted in future.

\section{Postscript: Ponti Venter on the role of philosophy}

Ponti Venter has often discussed and written on the issues just mentioned above (Venter 2004, 2006). Although in philosophical circles the gradual recognition of the humanities has been a well-known factor to deal with, in South Africa a sort of 'positivist' approach to many special sciences has survived its philosophical death. To visit the 'orphans ${ }^{\prime 6}$ of this movement, one has to descend to semi-dark laboratories and offices, after selecting certain subjects and certain circles (economics is said to be amongst the most affected). There one will encounter many academics who (settled in dark rooms, as one may imagine) proclaim their proud ignorance of and bitter disinterest towards all philosophy (sometimes including the philosophy of their own field of study). The irony is, of course, that they are often in the grip of a philosophy (or worldview?) that they don't take the trouble to examine.

Unfortunately, this attitude has often created considerable irritation amongst reformational scholars and, in the attempt to show the usefulness of philosophy, they have often fallen into some sort of over-reaction. If one adds the problem that (in reformational circles) the encyclopaedic role of philosophy has traditionally been a bit exaggerated (Coletto 2012a, 2012b, 2012c), one may start to understand why, in reaction to a dismissive attitude, in this tradition philosophy is sometimes depicted as the 'gearbox' of the vehicle (Wolters 1989:14-15), 'the discipline of the disciplines' (Strauss 2009), a sort of almighty omni-science, and omni-present in all the other disciplines.

Yet there are happy exceptions. It is sufficient to read Ponti Venter's (1999) 'The role of philosophy in the reformational Christian university' to notice the modest, balanced and appropriate picture which is drawn of the role of philosophy. I consider it as a sort of healthy exception, a happy manifesto on the humble yet meaningful task of the philosopher.

Venter explains that the 'foundations' of scientific theories, views or approaches are not the exclusive 'property' of philosophy. Philosophy, as a consequence, is 'foundational'

6. In the first part of this section the tone (which is not always obvious in written documents) is ironical. Should my choice of the term orphans sound inappropriate I would like to explain that it parallels J.M. Keynes' choice of the term slaves. With regard to economics he writes: 'Practical men who believe themselves to be quite regard to economics he writes: 'Practical men who believe themselves to be quite
exempt from any intellectual influences are usually the slaves of some defunct exempt from any intellectual influ
economist' (Keynes 1939:383). 
only in a certain sense (and is itself founded on a 'worldview'). There is, in fact 'more than one kind' of foundation (Venter 1999:198). Philosophy and foundational theory should therefore not be regarded as the same thing. Philosophy can of course help to analyse fundamental ideas, but its task is not to prescribe or dictate. Rather, its role is 'that of a collegial critic who uncovers, unmasks, suggests and above all listens and cooperates' (Venter ibid:198).

It is a recognition that avoids exaggerations and overreactions. It is also a return to the modest attitude attributed to Pythagoras ${ }^{7}$ who, after mentioning his modest knowledge of the 'sciences' of his time, explained: 'I am only a philosopher'.

\section{Acknowledgements Competing interests}

The author declares that he had no financial or personal relationship(s) that may have inappropriately influenced him in writing this article.

\section{References}

Academy of Science of South Africa (ASSAf), 2011, Consensus study on the state of the humanities in South Africa, Academy of Science of South Africa, Pretoria.

Barbour, I., 1990, Religion in an age of science, Harper \& Row, New York.

Botha, M.E., 1986, "'Bewitching" or confusing metaphysics? The demarcation between science and metaphysics according to Karl Popper', Koers 51(4), 430-440. http:// science and metaphysics according
dx.doi.org/10.4102/koers.v51i4.942

Cicero, M.T., 1957, Tusculanarum disputationum libri V, Teubner, Stuttgart. PMid:13394782

Coletto, R., 2011, 'Science and non-science: the search for a demarcation criterion in the 20th century', Tydskrif vir Christelike Wetenskap/Journal for Christian Scholarship 47(1), 63-79.

Coletto, R., 2012a, 'Encyclopaedic models in the Kuyperian tradition (Part 1: The "fathers")', Tydskrif vir Christelike Wetenskap/Journal for Christian Scholarship 48(1), 69-89.

Coletto, R., 2012b, 'Encyclopaedic models in the Kuyperian tradition (Part 2: From the 1970 s to the present)', Tydskrif vir Christelike Wetenskap/Journal for Christian Scholarship 48(2), 279-299.

Coletto, R., 2012c, 'Encyclopaedic models in the Kuyperian tradition (Part 3: Towards a network-model)', Tydskrif vir Christelike Wetenskap/Journal for Christian Scholarship 48(3), 43-63.

Comte, A., 1830-1842, Cours de philosophie positive, 6 volumes, Rouen, Paris.

7.The sentence is attributed to Pythagoras by both Cicero (1957:III, 7-9) and Diogenes Laërtius (1828-1831:I, 12). However, they both do so by referring to a lost book written by Heraclides Ponticus and some scholars doubt that the latter attributed the sentence to Pythagoras correctly.
Dilthey, W., 1989, Introduction to the human sciences, Princeton University Press, Princeton, N.J.

Feyerabend, P.K., 1975, Against method: Outline of an anarchistic theory of knowledge, New Left Books, London. PMCid:1681802

Habermas, J., 1971, Knowledge and human interests, transl. J.J. Shapiro, Beacon Press, Boston.

Habermas, J., 1984, 'Modernity: An incomplete project', in H. Foster (ed.), Postmodern culture, pp. 3-16, Pluto Press, London.

Hesse, M., 1980, Revolutions and reconstructions in the philosophy of science, Harvester Press, Brighton, Sussex.

Keynes, J.M., 1939, The general theory of employment, interest and money, Macmillan, London. PMid:20782270, PMCid:2209375

Kuhn, T.S., 1970, 'Reflections on my critics', in I. Lakatos \& A. Musgrave (eds.), Criticism and the growth of knowledge, pp. 231-277, Cambridge University Press, Cambridge.

Kuhn, T.S., 1996, The structure of scientific revolutions, The University of Chicago Press, Chicago. http://dx.doi.org/10.7208/chicago/9780226458106.001.0001

Laërtius, D., 1828-1831, De vitis, dogmatis et apophtegmatis clarorum philosophorum, Koehler, Lipsiae.

Lakatos, I., 1978, The methodology of scientific research programmes: Philosophical papers, vol. 1, Cambridge University Press, Cambridge. http://dx.doi.org/10.1017/ CBO9780511621123

Lyotard, J-F., 1984, The postmodern condition: A report on knowledge, Manchester University Press, Manchester.

Murphy, N., 1990, Theology in the age of scientific reasoning, Cornell University Press, Ithaca/London.

Popper, K.R., 1963, Conjectures and refutations: The growth of scientific knowledge, Routledge \& Kegan Paul, London.

Popper, K.R., 1970, 'Normal science and its dangers', in I. Lakatos \& A. Musgrave (eds.), Criticism and the growth of knowledge, pp. 51-58, Cambridge University Press, Cambridge.

Popper, K.R., 1976, 'The logic of the social sciences', in T.W. Adorno (ed.), The positivist dispute in German sociology, pp. 87-104, Heinemann, London.

Rickert, H., 1896-1902, The limits of concept-formation in natural science: A logical introduction to the historical sciences, 2 volumes, Cambridge University Press, Cambridge.

Rorty, R., 1991, 'Habermas and Lyotard on postmodernity', in I. Hoesterey (ed.), Zeitgeist in Babel: The postmodernist controversy, pp. 84-98, Indiana University Press, Bloominghton.

Storkey, A., 1986, 'The surrogate sciences', Philosophia Reformata 51(1), 110-116.

Strauss, D.F.M., 2001, 'Does it make sense to distinguish between the natural sciences and the humanities?', Tydskrif vir Christelike Wetenskap 37(1-2), 25-36.

Strauss, D.F.M., 2009, Philosophy: The discipline of the disciplines, Paideia Press, Grand Rapids.

Venter, J.J., 1999, 'The role of philosophy in the reformational Christian university', Tydskrif vir Christelike Wetenskap 35(3-4), 163-200.

Venter, J.J., 2004, 'Human dignity and the objectification of the human being: Subject, object and human dignity', Analecta Husserliana 79(3), 537-601.

Venter, J.J., 2006, 'A human(e) "uni-versity": Resisting scientism, technicism and economism', Koers 71(1), 275-318. http://dx.doi.org/10.4102/koers.v71i1.241

Weber, M., 1949, On the methodology of the social sciences, Free Press, Glencoe.

Wolters, A.M., 1989, 'On the idea of worldview and its relation to philosophy', in P.A. Marshall, S. Griffioen \& R.J. Mouw (eds.), Stained glass: Worldviews and social science, pp. 14-25, University Press of America, Lanham. PMid:2909874 